\title{
POST MUSEUM IN CAIRO (EGYPT)
}

\section{MARIAM MAGDY BOSHRA ${ }^{1}$, ENAS FARES YEHIA ${ }^{2}$, DOAA ABDEL-MOTAAL AHMED ${ }^{3} \&$ MOHAMED ATEF ABDEL-MAKSOOD ${ }^{4}$}

${ }^{1}$ Tourist Guidance Department, Minia University, Egypt

${ }^{2}$ Tourist Guidance Department, Princess Nourah Bint Abdulrahman University, Egypt

${ }^{3}$ Tourist Guidance Department, Minia University, Egypt

${ }^{4}$ History Department- Minia University, Egypt

\begin{abstract}
The Post Museum is distinguished by its ability to display collections in a simple manner suitable for all ages, combining the various departments in one place as it contains three-dimensional models for each period. These advantages are not available in a clear way in other museums. This makes the Post Museumwhich is located in Attaba Square in central Cairo, a tourist attraction for a large number of tourists from all parts of the world. The credit for the establishment of the Egyptian Post is due to Khedive Ismail after the purchase of the European Post Company, and the transfer of its ownership to the Egyptian government on January 2, 1865, as this day is considered a historic day for the Egyptian Post. Hence, the Egyptian Post Authority issued the first Egyptian post stamp in the Middle East in 1866. As for the establishment of the Cairo Post Museum, the credit goes to King Fouad, as part of the preparations that Egypt made before the tenth international conference in Cairo in 1934, so that the representatives of countries could see the museum to be the best evidence of the regularity of mail in Egypt; this article discusses the post museum with its ten division along modern Egyptian history, the most important point that Egypt possesses a rare collection museum in Cairo regarded as a witness for this long history.

KEYWORDS: Egypt, Post Museum, King Fuad, postal Conference
\end{abstract}

Received: Aug 14, 2020; Accepted: Sep 04, 2020; Published: Oct 06, 2020; Paper Id.: IJHRDEC20204

\section{INTRODUCTION}

Egypt was one of the first Arab countries to issue post stamps in 1866. It is also one of the first countries in the Middle East to establish a post museum in 1934, which contain pictures, maps, a group of graphs, and models of the development of the Egyptian postal service throughout ages. Also contains many documents such as: the first publication of the Post Service in its governmental era and the concession contract of the European Posta Company, in addition to a large rare wall painting on which are fixed 15 thousand stamps representing the scene of the pyramids and the Sphinx. Besides, The Egyptian Post Authority also confirms that the date of the first document in which the term "post" was mentioned dates back to 2000 years BC.Indeed, Egypt is an open museum for the whole world due to its civilization that extends to seven thousand years. It is one of the oldest countries in the world that witnessed the emergence of postal services.

Due to King Fuad's appreciation of the importance of choosing Egypt as the seat of the Tenth World Postal Conference in $1934^{1}$, after the ninth International Post Conference in London in $1929^{2}$, he decided to move the

${ }^{1}$ Egyptian National Archive, Archival Code,(001443-0069).

${ }^{2}$ Portfolio 8, File 1, Conservation Unit 309, Archival code, (000151-4015). 
headquarters of the main post office from Alexandria to Cairo in 1930. In the same year, he ordered the establishment of the "Fuad I Post Museum" "in Al- Attaba to be the first museum in Africa and the Middle East.The amount of money spent on it reached to 4430 poundsAnd, now post museum is considered one of the most important historical museums because ${ }^{4}$. it contains rare collections and important documents related to the history of the Egyptian Post. The Postal Authority started preparations for the establishment of the museum, by completing all the papers and searching for documents related to the history of the mail that is important to display in the historical section within the Post Museum to be created, in preparation for its opening in conjunction with the holding of the $10^{\text {th }}$ Postal Conference ${ }^{5}$ in Cairo.So King Fuad ordered the establishment of a post museum in which he would include all the treasures of the past to show off and be proud of the history of Egyptian Post through the historical eras that had existed since the time of the Pharaohs. And to emphasize that Egypt was a pioneer in the use of postal service transport systems before all peoples. He ordered a search of all historical documents, old letters and manuscripts to preserve them from loss $^{6}$, especially related to the purchase of the European post company, which became an Egyptian company by Khedive Ismail on January 2, 1865 .

\section{The importance of the Post Museum}

The Egyptian Post Museum has many roles, and perhaps the most important of which is the educational role, due to the historical information and archaeological holdings it provides to visitors, scholars and researchers as it provides all the facts and evidence that were difficult to obtain in case of not establishing the museum, including the archaeological holdings and unpublished documents.

The museum contains 1250 rare pieces and is divided into ten sections in two halls ${ }^{8}$, one of which is called the Great Hall, which contains nine sections and includes models for old and modern postal seals, postal bags and letter boxes, pictures for old and modern postal departments ${ }^{9}$, in addition to the basic make-up of the current building of the Post Authority, besides three-dimensional models of the means of transportation that were used to transport post. The museum also includes the emblems of old postmen and various examples of developments in airmail, from carrier pigeons to planes.Also contains the buildings section, which includes miniature models of some postal buildings, such as the Postal Authority in Cairo, the Port Said and Port Fuad Post Offices. And a set of statistics that show the development of the Authority's work, including registered and regular correspondence, internal and external transfers and parcels ${ }^{10}$. The museum also includes models of some of the aircraft donated by the Empire's airways and the Dutch airline. In addition to the first letter by air mail sent to Karachi from the Egyptian Post by air between the Egyptian country and India, and a sample of the first letter that came to Alexandria from London on August 17, $1929^{11}$.As for the small hall, it includes a large set of stamps for each of the Egyptian, African, Asian, American, Australian and European post besides

${ }^{3}$ Egyptian National Archive, Portfolio 10, File 1, Conservation Unit 281, (ARC 000074-4024).

${ }^{4} \mathrm{Al}$ Ahram, $19^{\text {th }}$ January 1940, issue 19886.

${ }^{5}$ Egyptian National Archive, Archival code(001443-0069).

${ }^{6}$ Hussein Sherazy, Qesat Albareed, ( Cairo: Dar Elketab Alaraby, 1967), 28-29.

${ }^{7}$ Egyptian National Archive, Portfolio 1, File 3, Conservation Unit 309, Archival code(000003-4015).

${ }^{8}$ Abd Elrahman Zaki, Mawsact Madinat Alqahra fi Alf Am, $8^{\text {th }}$ edition, ( Cairo: Anglo press, 1987), 24.

${ }^{9}$ Ahmed Yasser, "postal Museum: Reference for stamp Collectors in Egypt", in Sada El-balad journal, Wed. 19/12/2018 24/1/2019, 12: 26pm (,Thurs).

${ }^{10}$ Majalt Alarab, $10^{\text {th }}$ October 2016, issue 10420.

${ }^{11}$ Transportation ministry, Maslaht Albareed, Daleel Mathaf Albareed Almasry,( Cairo: Amiria Press, 1934), 40-42. 
inkpots from the Ancient, Roman, Coptic and Islamic periods. There is also a set of forms to explain the steps involved in making postage stamps at the Survey Authority in Cairo.

\section{First: the cultural importance of the Post Museum}

The museum's cultural role is evident in organizing a group of exhibitions that help encourage citizens, school students and families to visit the museum, whether inside or outside Egypt. Besides, the Post Museum participated in organizing many local and international exhibitions of Egyptian and foreign stamps. In addition, the post authority organized a huge exhibition in Cairo in 1946 to mark the $80^{\text {th }}$ anniversary of the issuance of the first Egyptian post stamp in addition to the museum's participation in the holding of the Centennial International Exhibition of Post Stamps in Paris and the Centennial International Exhibition of Post Stamps in Brussels. In 1950, the post Authority participated in organizing foreign exhibitions, including the Egyptian Stamps Exhibition in the United States. In 1966, the Post Authority participated in organizing the first regional exhibition in Menoufia Governorate, and it was awarded a commemorative certificate of excellence on the occasion of participating in the exhibition ${ }^{\mathbf{1 2}}$.

\section{Second: the historical importance of the Post Museum}

The historical importance of the museum becomes clear through its holdings, as it contains the oldest historical documents that proved the existence of a mail system in the era of the Pharaohs and an express system during the Ptolemaic era in addition to photographs of a group of papyrus dating back to 111 years BC. There were also unpublished documents related to international postal conferences from the first international postal conference in Switzerland in $1874^{13}$ until the eleventh postal conference in Buenos Aires in 1939 ${ }^{14}$. All this was inside the Post Museum, which was established in $1930^{15}$ to become an eternal record of the history of the Postal Service and a witness to the efforts undertaken by the Authority and an incentive to continue progress towards improving postal service in Egypt and to be the best evidence of what Egypt possesses of rare collections dating back to thousands of years. This is in addition to the importance of the museum in strengthening the relations with many countries around the world while attending international postal conferences, the most important of which is the holding of the tenth international post conference in Cairo in 1934 for which the Egyptian Post Authority prepared an integrated global conference that included all means necessary for the success of the conference in terms of Organizing and arranging to facilitate meetings of the conference and its committees $^{16}$.

The historical importance of that period during the reign of king Fuad was not limited to everything related to postal services such as holding conferences ${ }^{17}$ or opening museums only. Indeed, Egypt has witnessed many international conferences held on its soil in all fields. These included international conferences on medicine ${ }^{18}$, tourism $^{19}$, agriculture ${ }^{20}$,

12 Mohaamed Fawzy Abdelqader, Vector Anton Ibrahim, Rwad Albared Almasry, ( Cairo: Alheah Alqwmia llbareed, 2010), 175:200.

${ }^{13}$ Egyptian National Archive, Archival code(001443-0069).

${ }^{14}$ Egyptian National Archive, Portfolio 61, File 12, Conservation Unit 198, Archival code(001449-0069).

${ }^{15}$ Al Ahram, $19^{\text {th }}$ January, 1940, issue 19886.

${ }^{16} \mathrm{Al}$ Ahram, $2^{\text {nd }}$ February 1934, issue 176560.

${ }^{17}$ Egyptian National Archive, Archival code(001443-0069).

${ }^{18}$ Egyptian National Archive, Portfolio 60, File 1, Conservation Unit 198, Archival code(001429-0069).

${ }^{19}$ Saleh Abdoon, Khamsoon Amn mn Almwseqa wa Alopera, (Cairo: Dar Alshrooq, 2017), 101. 
aviation $^{21}$ and railways ${ }^{22}$ due to its great importance in sending a clear message to the whole world, the independence and strength of Egypt in preparing such conferences on its soil as well as emphasizing that Egypt is the country of security and safety. That was due to what each conference demands from the entire state apparatus that must intensify protection on vital buildings, entrances and exits to protect the important figures coming to attend such conferences. Also, the Post Museum contributed to strengthening the relations with the West and the East. This is evident in the various gifts presented to the Post Museum ${ }^{23}$. Examples include a gift from the Chinese International stamp collectors Exhibition in 1999 and a glass frame as a gift from the third Arab Exhibition of Post Stamps in Medina, Saudi Arabia in addition to a sword and trumpet for Sweden's postal guard from the last century, a collection of photographs, postmen costumes and European models of overseas mail ${ }^{24}$.

\section{Third: the tourist importance of the Post Museum}

The tourist importance of the museum becomes clear in its collections which attract thousands of tourists annually worldwide to see the history of the Egyptian post throughout the ages. This is because the Post Museum is the first framework of reference for stamp collectors and a resource that attracts many tourists from all countries of the world because the museum has hundreds of thousands of stamps, some of which exceed 150 years of issuance.Perhaps the most important for stamp collectors is the small hall that includes a large collection of post stamps from most of the countries of the world, which tell us a long history through which the world's civilizations are illustrated with all their traditions, customs, symbols, literature and arts, in addition to the historical events of each country. These types are called commemorative stamps ${ }^{25}$ that motivate millions to follow up new publications to learn about recent discoveries, conferences, celebrations, world events, national events, sports and art on the post stamps for the purpose of advertising to stimulate tourism and spread culture.

\section{Fourth: the political importance of the Post Museum}

The political importance of the museum is represented in strengthening Egypt's relationship with the outside world when King Fouad decided to establish a post museum within the authority. Many ministries, directors and employees have come forward to provide aid to the museum to be established ${ }^{26}$, such as the directors of London, Brussels, Berlin and Cairo museums, and the ministers of Egypt in London and Berlin, directors of air and maritime navigation companies and the Federation office in Switzerland, the staff of the School of Applied Arts, the Emiri Press, and the Railways and Survey Authority to provide all support to help the Egyptian Post Authority on the occasion of establishing its new museum ${ }^{27}$. This cooperation on the part of the countries confirms the necessity of establishing an Egyptian Post Museum in order to include rare mail collections and its importance in consolidating political relations internally and externally by hosting dignitaries from all countries of the world by the museum during the museum's opening, international postal conferences and official

${ }^{20}$ Samy Mohamed Feraj, Bareed Masr Almahrwsa tht Hkm Osrat Mohamed Ali(1914-1957), vol.2, ( Cairo: Dar Elreda, 2017), 101.

${ }^{21}$ Ahmed Hussein Hafez, Swaran Tahky Tareekh, ( Cairo: Almanhal , 2014), 22.

${ }^{22}$ Alwaqac Almasria, $16^{\text {th }}$ October 1930, issue 96.

${ }^{23}$ Ministère des communications : Administration des postes ‘"Guide du Musée postal égyptien، (Imprimerie National Le caire، 1934) P 29: 30.

${ }^{24}$ Transportation ministry, Maslaht Albareed, Daleel Mathaf Albareed Almasry, 42-43.

${ }^{25}$ Zeitouna, "150 years of Egyptian Postage 1866-2016",(first edition, Dar El Kutub, Cairo, 2015).

${ }^{26}$ Egyptian National Archive,Portfolio 1, File 3, Conservation Unit 309, Archival code (0000o3-4015).

${ }^{27}$ Abd Elhaleem Abu Seer, Ismail Abdelfatah, Jawla Dakhel Mathaf Albareed, ( Cairo: Alhaea Alamah Llestalamat, 1999), Tansportation Ministry, Maslaht Albareed, Daleel Mathaf Albareed Almasry, ( Cairo: Amirira press, 1934). 
visits. This is what the Minister of Transportation was invited to during the opening of the Tenth International Postal Conference in Cairo in 1934 after welcoming representatives of the countries of the Universal Postal Union, inviting them to visit the archaeological sites and historical monuments scattered in Egypt ${ }^{28}$. Of course, such visits result in a strengthening of diplomatic relations with other countries.

The Post Museum includes a large collection of commemorative post stamps that publicize and advertise at home and abroad in multiple languages in all agricultural, industrial, educational, urban, tourism, cultural, archaeological, religious and political fields. This propaganda is considered a good way for the country around the world to represent all important historical and national events that the country is going through on post stamps. Among the important publications of commemorative stamps for the purpose of publicity are the opening of Fouad I Institute for the Sahara, stamps for the Diamond feast of the Geographical Society, the Silver Day of Fouad I University, and stamps for Fouad I Post Museum ${ }^{29}$.

\section{Post Museum Establishment}

The museum is located on the second floor of the Post Authority ${ }^{30}$; this treasure is in two halls, one of which is the main hall, the grand hall, which includes nine sections. The other is the small hall that includes portraits of Egyptian rulers from the family of Muhammad Ali and stamps for all countries of the world.After climbing the stairs and reaching this floor we find a large courtyard in the middle of which is a huge star on the floor. It is the center of Cairo from which the distance is measured between the Post Authority in Cairo and the post centers all over Egypt. In the middle of this star is a huge statue of Khedive Ismail who initiated the idea of purchasing the European Post and transferring it to the Egyptian Post Authority

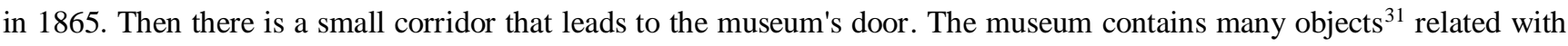
the history of the Egyptian Post. The most important of them is the historical section that contains samples of the development of writing and the transmission of the letter across different. It also includes a section for conferences that contains pictures of members of the international postal conferences from 1874 to $1939^{32}$ in addition to postal treaties and agreements of each conference. And other sections on postal tools, maps, statistics, mail boxes, transportation, and Egyptian and foreign stamps ${ }^{33}$.

${ }^{28}$ Alahram, $2{ }^{\text {nd }}$ February, 1934, issue 176560.

${ }^{29}$ Egyptian National Archive, Portfolio 10, File 1, Conservation Unit 281, Archival Code, (000074-4024).

${ }^{30}$ Almoqatm, $18^{\text {th }}$ January 1940, issue 15705

${ }^{31}$ Abd Elrahamn Zaki, Mawsact Madinat Alqahia fi Alf Am, 241.

${ }^{32}$ Egyptian National Archive, Portfolio 61, File 12, Conservation Unit 198, Archival code(001449-0069).

${ }^{33}$ Majalet Alarab, $10^{\text {th }}$ October, 2016, issue 10420 


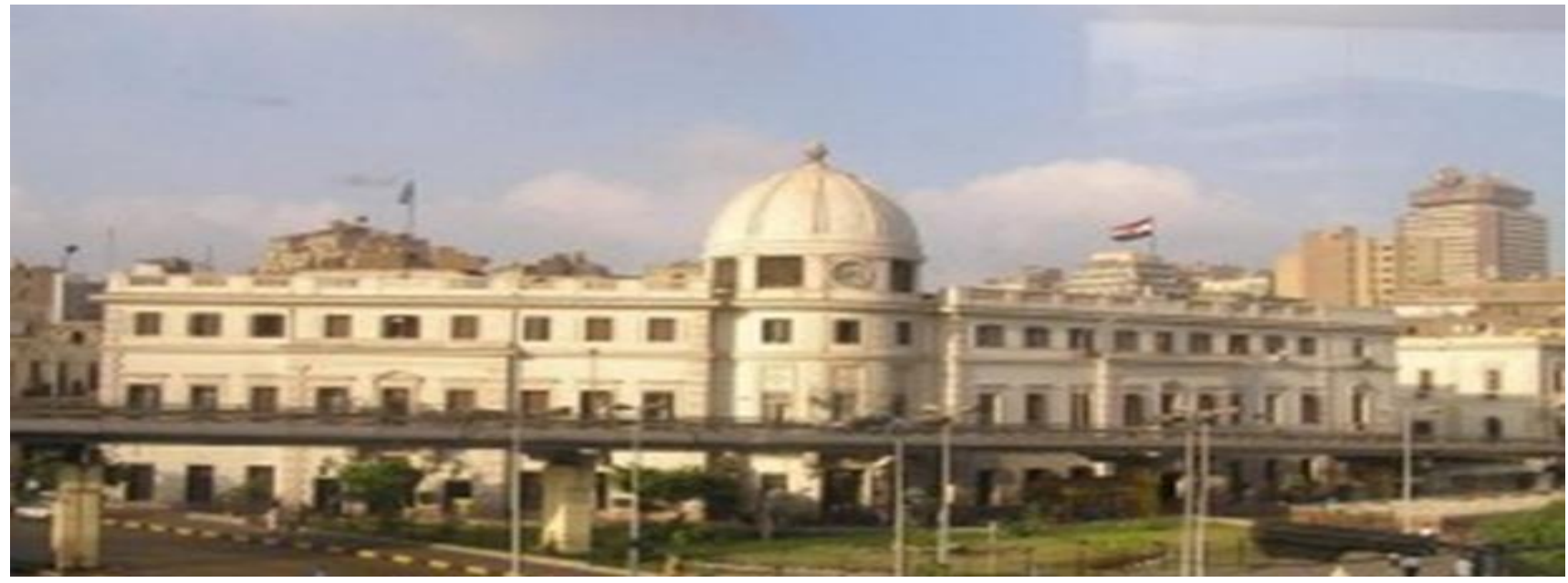

Figure of the General National Authority of Egyptian Post in which the museum was builtat El Attaba.

From the guide book of the post museum 1934source:

After entering through the wooden door leading to the Post Museum, we find a small corridor with a group of photographs, including a large honor board for members of the National Post Authority who took over management of the Authority since 1865 until now, in addition to a group of pictures of members of some international conferences. Then we reach to the museum's two showrooms (halls). We find the small hall of the stamp section on the left, and the large hall of the other nine sections on the right.

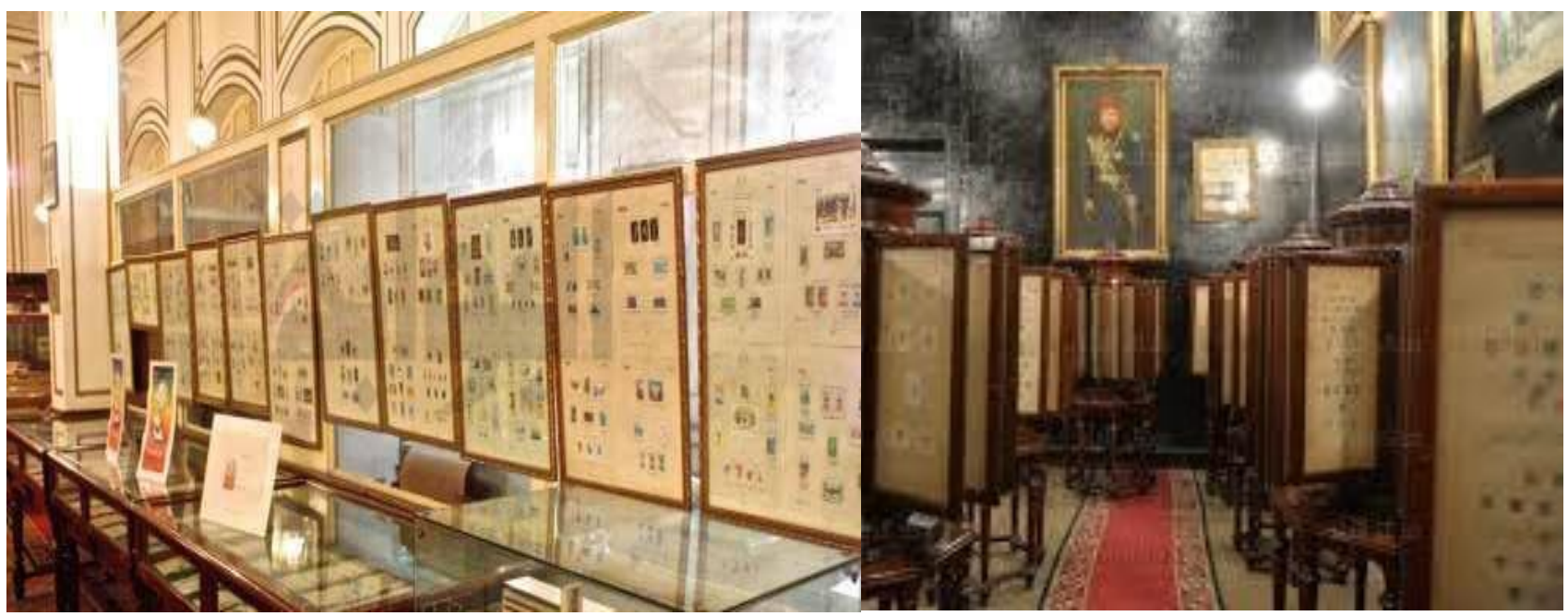

Figure 1:The Grand and small Hall of the Post Museum

\section{Source: "Photographed by Authors"}

King Fuad I decided to establish a post museum to receive the coming delegations to attend the 10th International Postal Conference in Cairo in 1934, so that visitors from all over the world could see the museum and its objects. The Authority was interested in the decision to establish a "Post Museum" issued by King Fouad and began to arrange the objects and collect all documents related to the postal service to place them in the historical section inside the museum. 
This is clearly mentioned in one of the documents of the Post Authority dated 15 July $1933^{34}$.

In 1934, it was inaugurated for the first time during the period of the 10th International Post Conference in Cairo so that VIPs can visit it during the conference ${ }^{35}$.In 1940, it was officially opened to the public after it was fully finished ${ }^{36}$.In 1944, the museum was closed during World War II and after the war ended, the museum's objects were returned after they were hidden in hiding places and the museum was reopened in $1944^{37}$.In 1989, it was opened on February 7 , 1989, after making renovations to the museum during the era of President Hosni Mubarak.

Renovations are underway at the Post Museum since September 2019 during the era of President Sisi and the current post manager, Mr.Issam Al-Sagheer.

\section{The way to register objects in the Post Museum}

Through my frequent visits to the museum, researching in many references and sources, as well as taking photos of the majority of the museum's objects and checking the information labels next to each object inside the museum, I was able to know the method used to record objects inside the museum, as follows:

First: name of the museum is first written, the name is mentioned in two ways, either writing the "Post Museum" or "Fouad I Post Museum".

Second: The language used to record Arabic and French data.

Third: The section of each piece is written; the museum contains ten sections.

Fourth: piece number is written.

Fifth: full data is recorded on a label next to each object.

Sixth: name of the entity from which the object was obtained.

For example, in the information labels shown before us, it is clear in the first label on the right side that it is a gift presented by Heliopolis Palace Hotel in 1934 on the occasion of the Tenth Postal Conference in Cairo ${ }^{\mathbf{3 8}}$. The second is for a statue of the scribe dating back to the Pharaohs age that was found in the pyramid excavations. As for the third label, it shows different samples of stamp designs made by the National Post Authority.

\footnotetext{
${ }^{34}$ Egyptian National Archive, Portfolio 5, File 2, Conservation Unit 309, Archival Code (000052-4015).

${ }^{35}$ Egyptian National Archive, Archival Code (001443-0069).

${ }^{36}$ Alahram, $19^{\text {th }}$ January, 1940, issue 19886.

${ }^{37}$ Mohamed Fawzy Abdelqader, Vector Anton Ibraheim, Rwaad Albareed Almasry, 151-152.

${ }^{38}$ Egyptian National Archive, (001443-0069).
} 


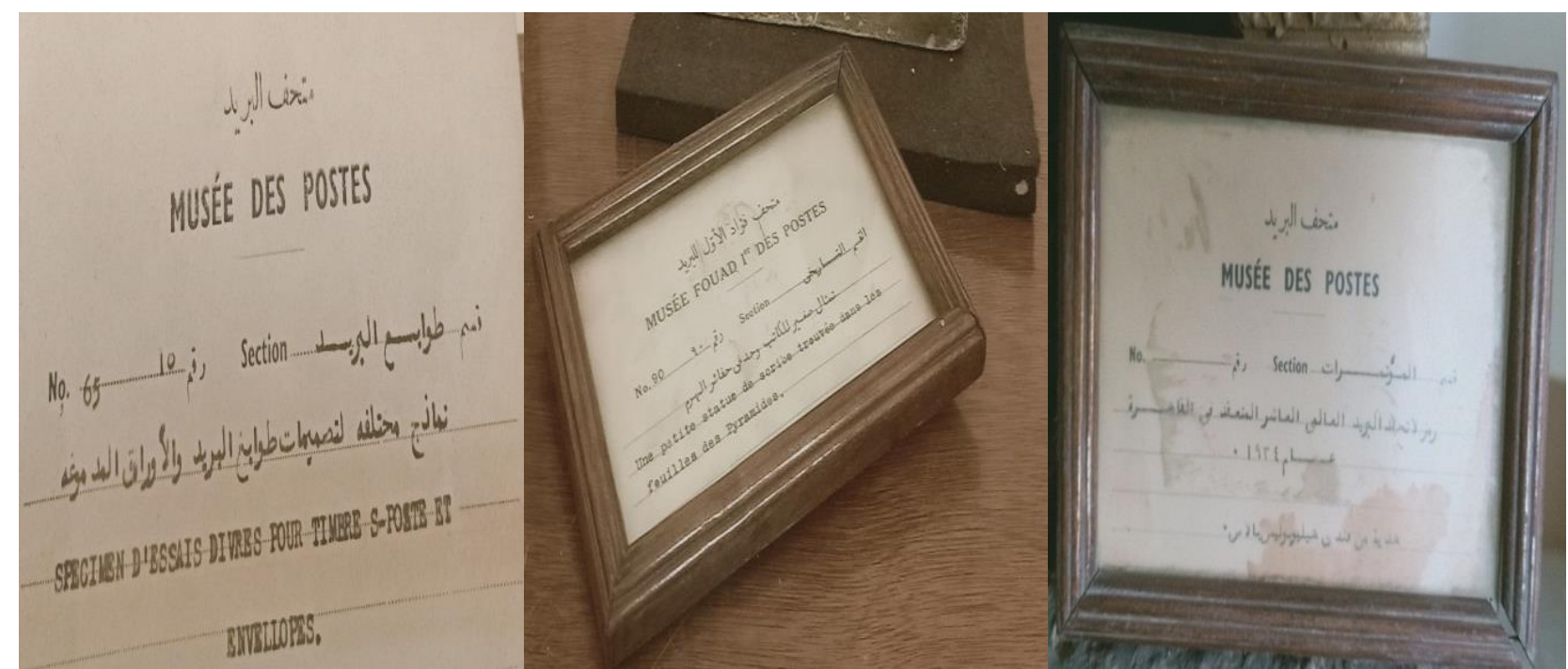

Figure 2: Instructional boards inside the Post Museum to illustrate the way in which the objects are registered.

\section{Source:"Photographed by Authors"}

\section{Museum's Collections}

At the inauguration of the Post Museum at El-Attaba in 1940, the museum was divided into twelve sections ${ }^{\mathbf{3 9}}$, but later it was re-divided again into currently ten sections only.We Will display the most important objects inside the museum: -

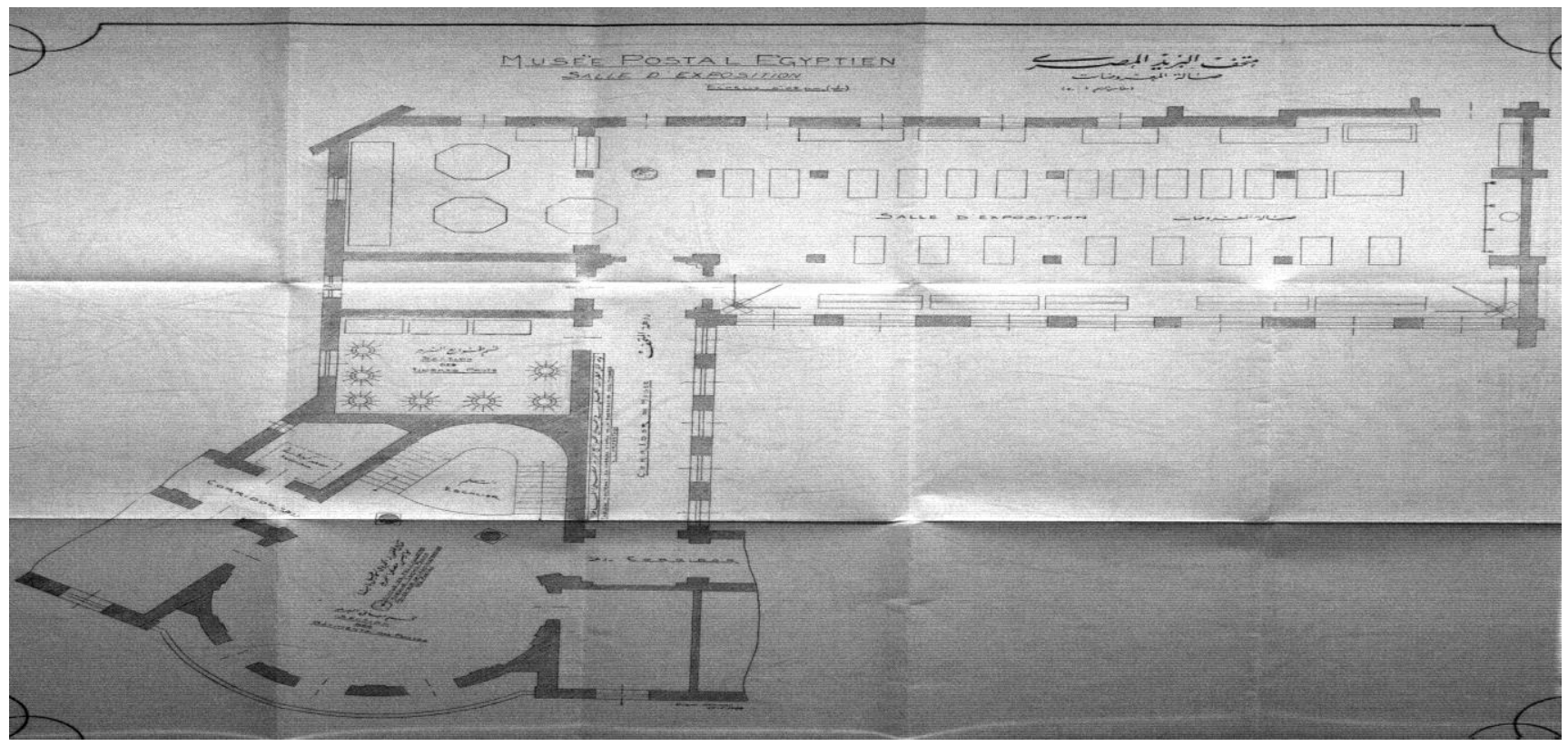

Figure 3: Interior design of the museum showing the large and small hall

Source: From the guide book of the post museum 1934

${ }^{39}$ Almoqatem Newspaper, $18^{\text {th }}$ January, 1940, issue 15705. 


\section{First: The Historical Section ${ }^{40}$}

This section contains "Narmer painting ${ }^{41 "}$ : which dates back to the first dynasty and bears the oldest understandable writing. An Inkpot from the Pharaonic era and a mill for crushing ink materials, an Inkpot from the Roman era and Inkpot from the Coptic era are also included. Also, "Rosetta Stone": found by one of the men of the French campaign in August 1799near the city of Rashid. It had inscriptions on it in three languages, and the French scholar Champollion was able to decode $\mathrm{it}^{42}$.

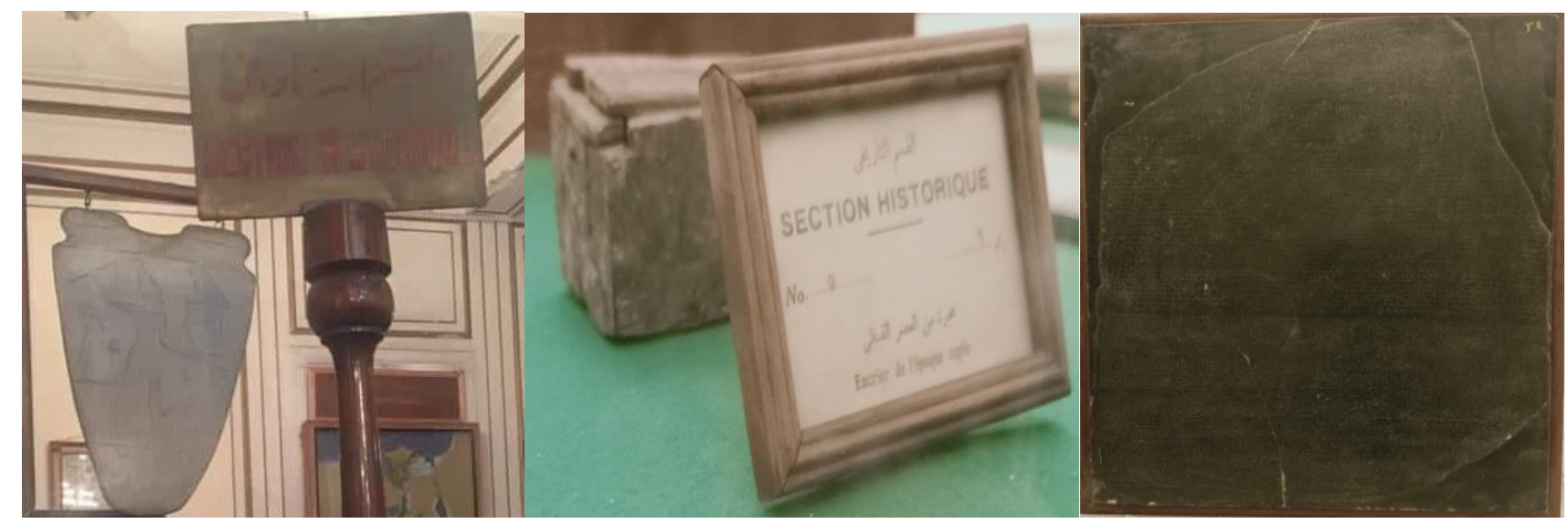

Figure 4: Narmer painting, an Inkpot from the Coptic eraandRosetta Stoneinside the historical section

\section{Source:"Photographed by Authors"}

A photocopy of the document of Al-hiba dating back to the third century BC, and it is considered one of the oldest postal documents that proved the regularity of the express post movement in Egypt during the Ptolemaic era.Also, photograph of the Papyrus Elixir of Hinos 710, which follows the document ofAl-hiba, in terms of antiquity dating back to 111 years BC. It included the number of employees in a post office in a town located in Fayoum.

A contract between the European company and the Suez Canal Company, tariff of the transmission of correspondence by the European company in the year 1860, a contract between the Traffic Authority and the European Post Company in the year 1861, a Franchise Contract for the European Post Company in 1862. An announcement of the use of the first postage stamps in 1866 and the first tariff of the transmission of internal correspondence in 1866. Also,an announcement of putting postal boxes in the streets in 1866and group of Maps for transporting postal services.

\section{Second: Postal tools, letter boxes and Stamps Department ${ }^{43}$}

A set of scales for correspondences, scale for the weight of the gold and silvercoin, mechanical metric scale, scale with an arm to weigh the parcel, large and small baskets of willow to sort correspondence, English Permissions Portfolios.

\footnotetext{
${ }^{40}$ Wezarat Almwaslat, Daleel Mathf Albareed Almasry, $1: 6$.

${ }^{41}$ It is a memorial plate commemorating the victories of King Narmer, founder of the First Dynasty in 3200 BC, who was able to unite the Kingdom of the South with the North. This painting was discovered in 1898 in the city of Hirakonouples. ${ }^{42}$ Abd Elhaleem Abu Seer, Ismail Abdelfataf, Jawla Dakhel Mathaf Albareed, 36.

${ }^{43}$ Ministère des communications:Administration des postes, "Guide du Musée postal égyptien, P 11:18.
} 


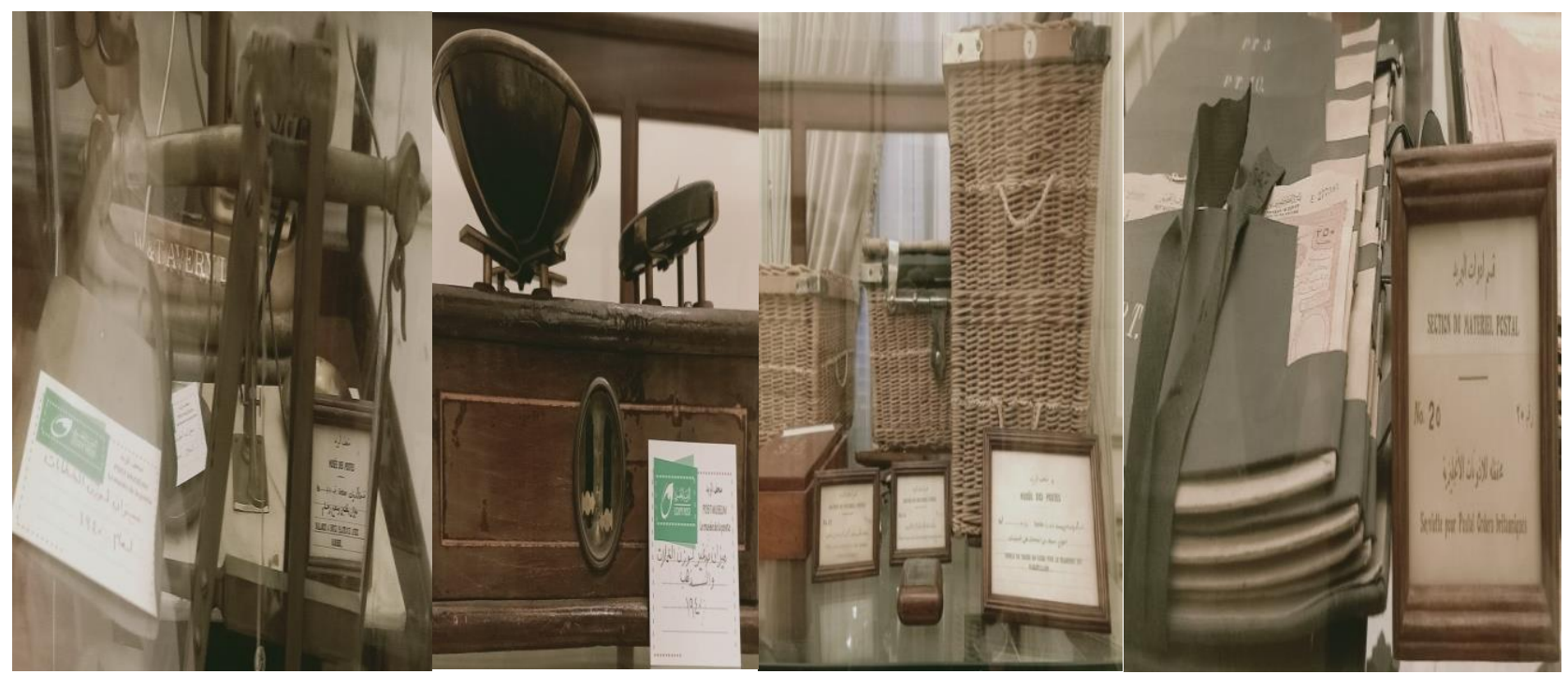

Figure 5: old scales used to weigh correspondence, currencies and gold in 1940,sample baskets for sorting postal items, and English Permissions Portfolios.

\section{Source:"Photographed by Authors"}

A letter boxes made in Egyptused in postal services, an English style mechanical letter box, Austrian letter mechanical box for airmail ${ }^{44}$, Sweden Letter Box,sample box for publications, samples and worksheets.Another letter boxes made of wood and iron, letter boxes for ships, boxes for prints and samples ${ }^{45}$.

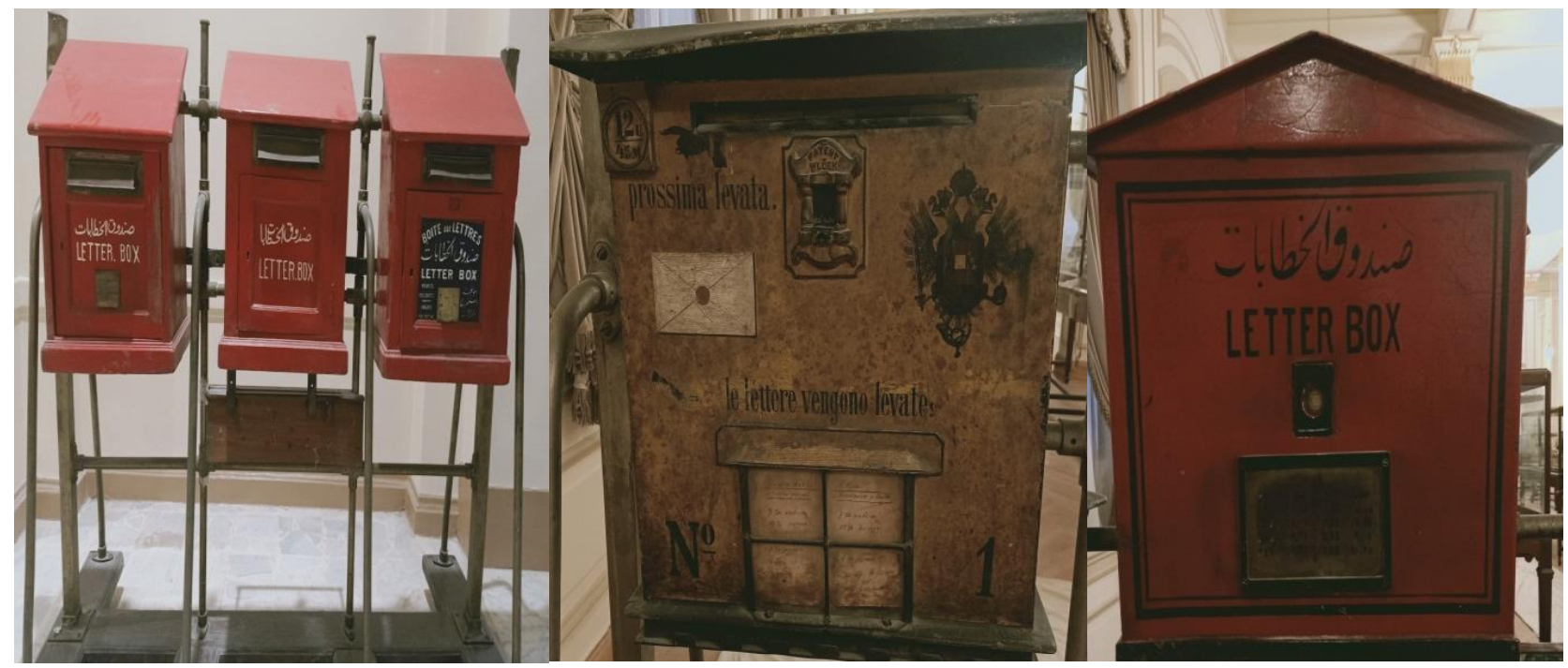

Figure 5: group of various letters boxes inside the museum.

Source:"Photographed by Authors"

${ }^{44}$ Majalt Alkarab, $10^{\text {th }}$ October 2016, issue 10420

${ }^{45}$ Abd Elhaleem Abu Seer, Ismail Abdelfataf, Jawla Dakhel Mathaf Albareed, 23:36. 


\section{Third: the clothing Department ${ }^{46}$}

The general manager of the post authority, "Motsi Bey", brought formal clothes for the post employees ${ }^{47}$ in 1866 for the senior officials to wear in the official and Khedivial ceremonies or in the event of His Highness Khedive's visit to the post authority. And the clothes were admired by Khedive Ismail at the party held in July 1866.

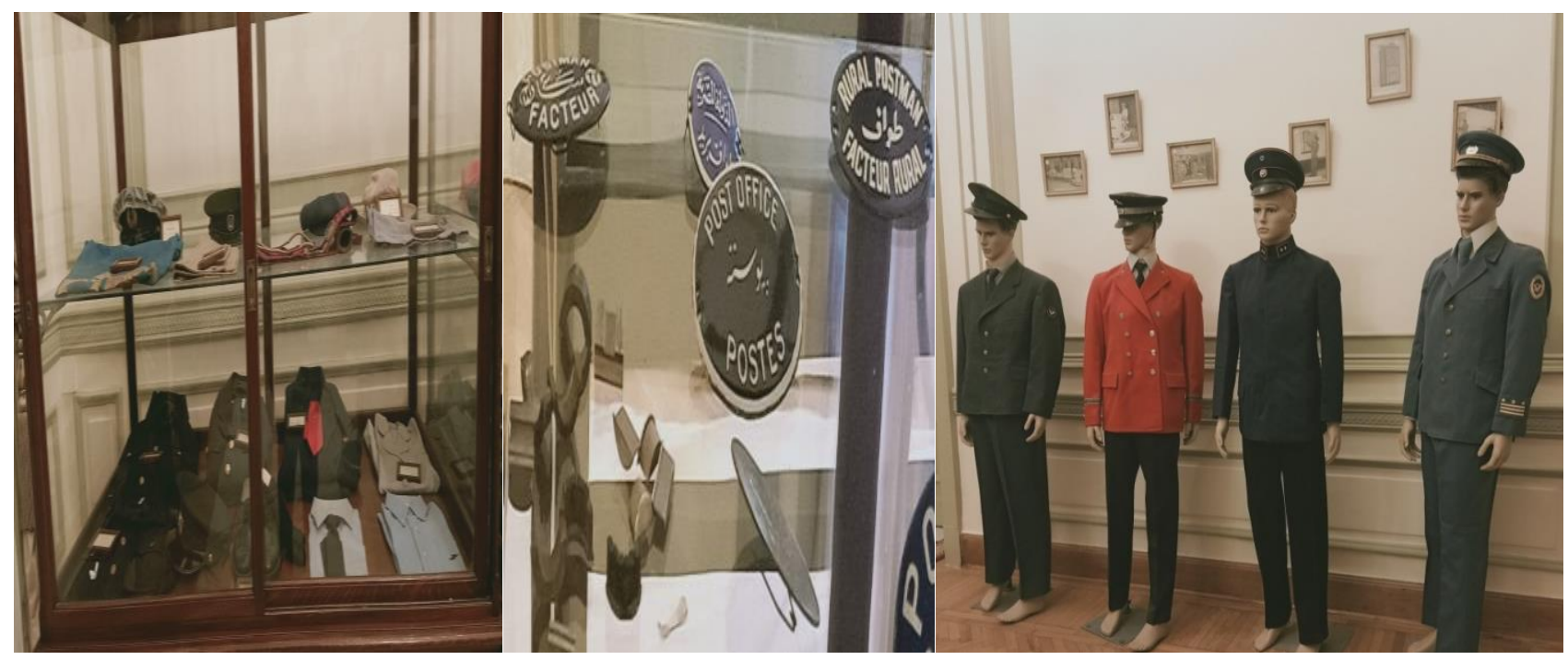

Figure 6: Group of old postmen clothes and different badges

\section{Source: "Photographed by Authors"}

\section{Fourth: Post Buildings Department ${ }^{48}$}

This section includes stereoscopic models and illustrations of the buildings of the Postal Authority in Cairo, the postal departments in Port Said, Port Fouad, Aswan, and a village post office in the Quesna, a model of the Cairo Postal Distribution section, the Continental Hotel, the main post office and movement building at Ramses Street, and other building $s^{49}$. A model of the general administration for the Postal Authority in Cairo, the distribution department model and Village Post Office model ${ }^{50}$. Port Fouad post office model,Aswan post office model, Continental Hotel Post Office model and Port Said Post Management Model.

\footnotetext{
${ }^{46}$ Ministère des communications: Administration des postes, "Guide du Musée postal égyptien, P 19:21.

${ }^{47}$ Abd Elrahman Zaki, Mawswact Madinat Alqahra fi Alf Am, 240.

${ }^{48}$ Wezarat Almwaslat, Daleel Mathf Albareed Almasry,32.

${ }^{49}$ Abd Elhaleem Abu Seer, Ismail Abdelfataf, Jawla Dakhel Mathaf Albareed, 37.

${ }^{50}$ Majalt Alkarab, $10^{\text {th }}$ October 2016, issue 10420
} 


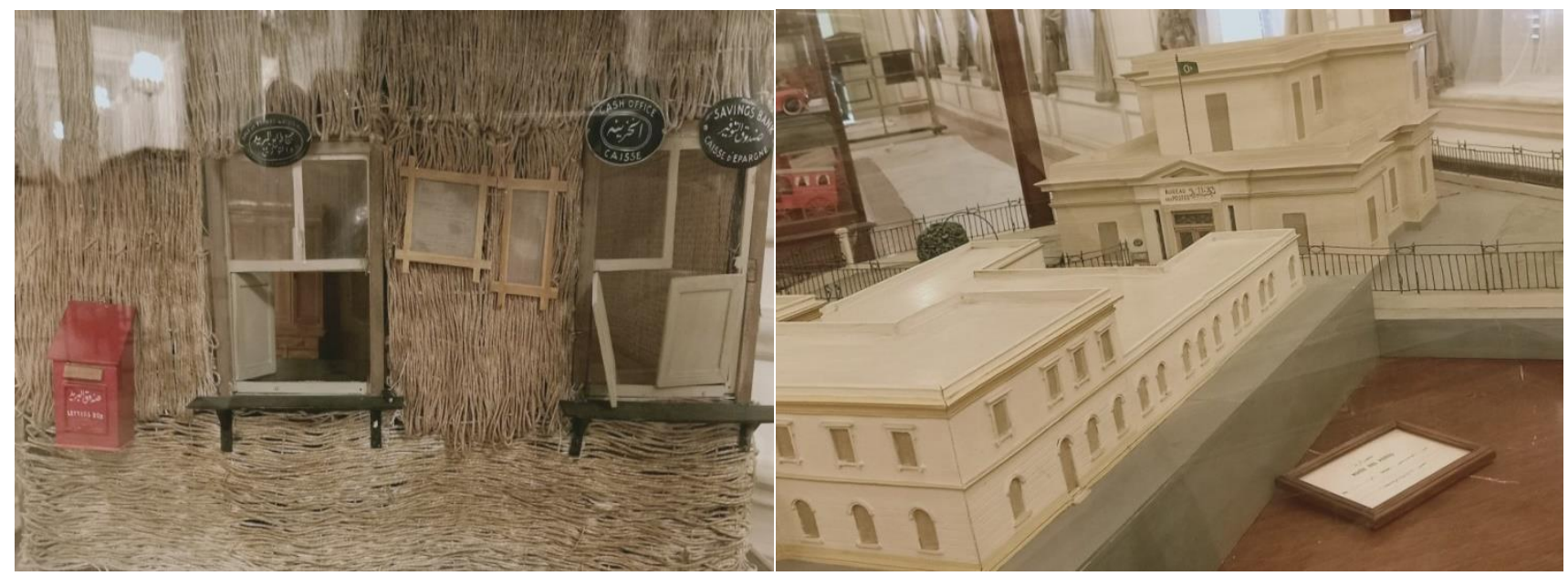

Figure 7: A village post office template and Port Said Postal Administration model.

\section{Source:"Photographed by Authors"}

\section{Fifth: Department of Statistics, Graphs, Maps and Photographs}

Interior work, regular letters and correspondence, exterior works, registered correspondence, savings, deposit and withdrawal fund, express post, airmail, postal tickets, newspapers, publications, worksheets and samples. And a Photo collection of post in $\mathrm{Egypt}^{51}$ and map of post offices in 1932.

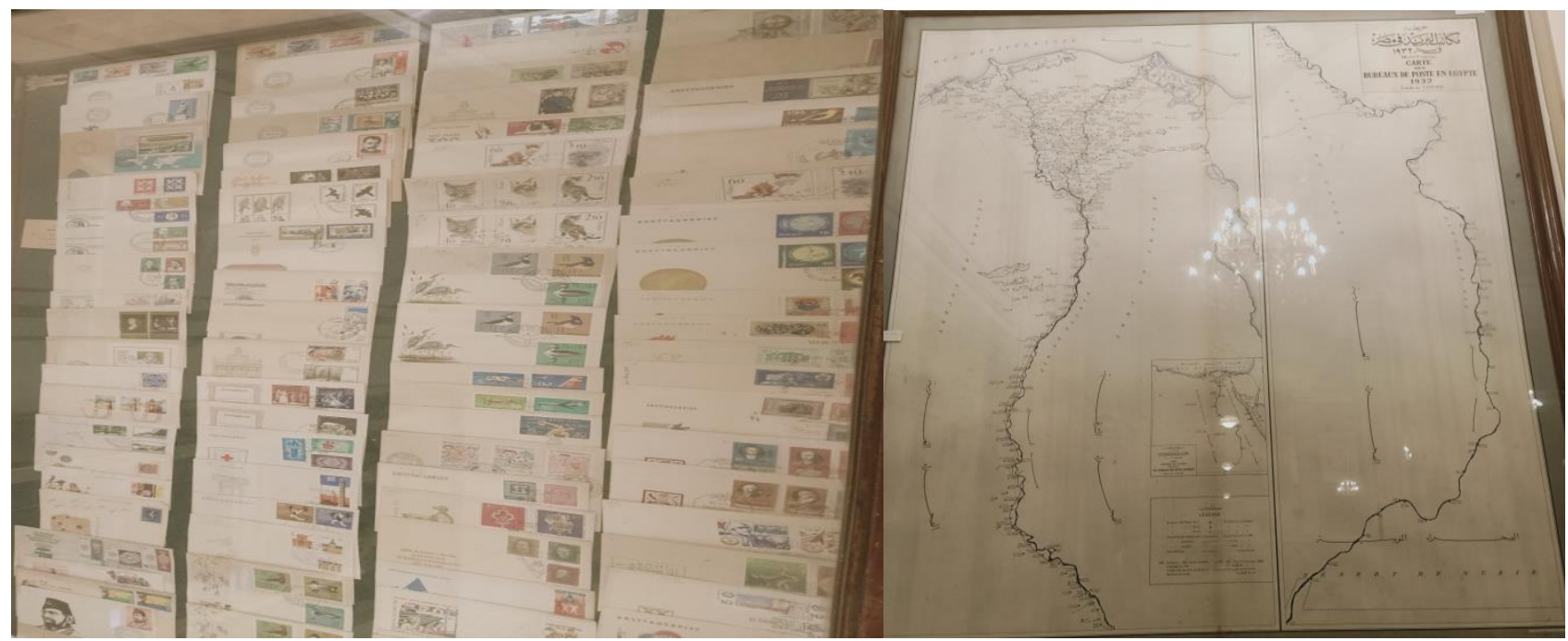

Figure 8: a group of letters and post offices map in Egypt in 1932

\section{Source:"Photographed by the Authors"}

\section{Sixth: The Transportation Department ${ }^{52}$}

This section Contains Cable car model thatused as a means of transportation in unpaved places.

${ }^{51}$ Abd Elrahman Zaki, Mawswact Madinat Alqahra fi Alf Am, 240.

${ }^{\mathbf{5 2}}$ Wezarat Almwaslat, Daleel Mathf Albareed Almasry, 36:39. 


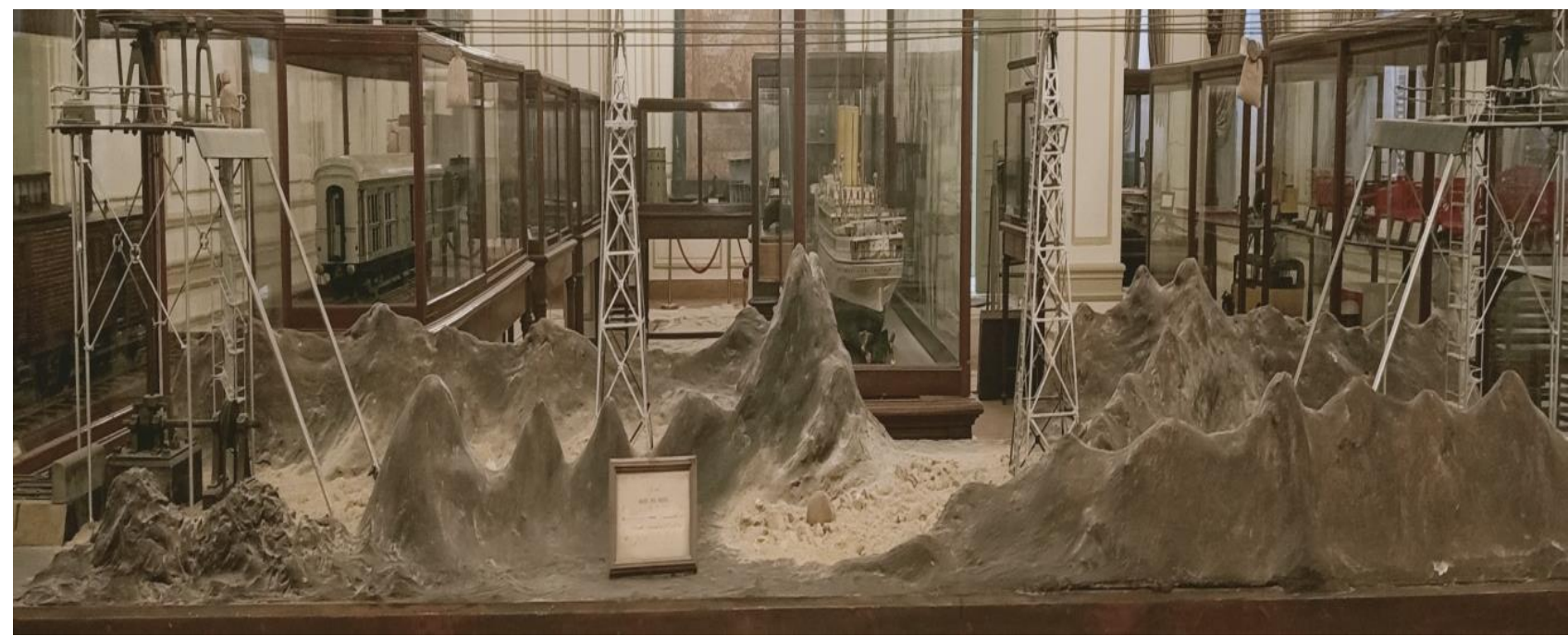

Figure 9: cable car model "Teleferik".

\section{Source:"Photographed by Authors"}

Also, contains Two-wheel trolley model for transporting heavy objects, wooden handcart covered with wire to transport the parcels, model of a two-wheeled wood trolley, model of a two-wheeled wood trolley with iron wheels, Fourwheeled wood cart model without windows, four-wheeled vehicle model, model of a trolley with two wheels on the back and one on the front.Besides, a model of a railway six-wheeled vehicle, model of a railway four-wheeled vehicle, model of a camel for transporting post between Qantara and Al-Arish ${ }^{53}$ and model of a steamship for transporting post between Kafr El-Zayat and Edfina.

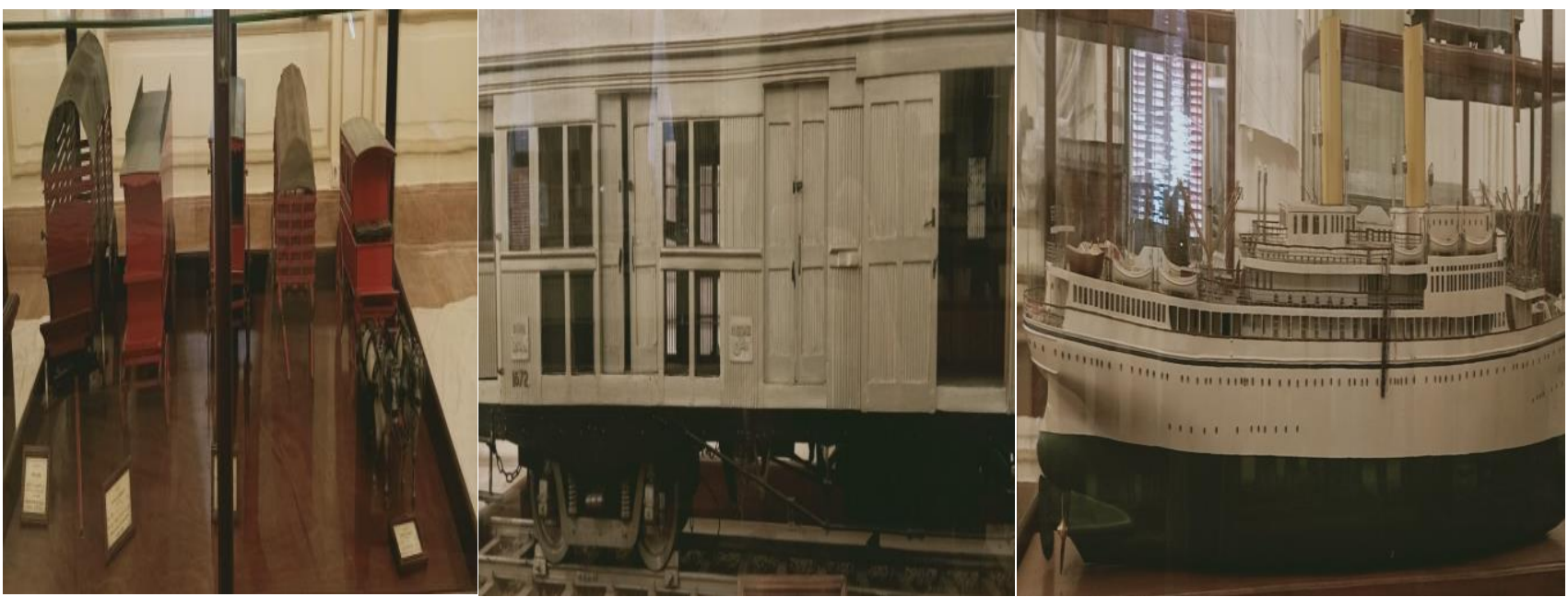

Figure 10: models of the wheels, a six-wheeled railroad cart model and model of one of the ships for transporting post.

Source:"Photographed by the Authors"

${ }^{53}$ Abd Elhaleem Abu Seer, Ismail Abdelfataf, Jawla Dakhel Mathaf Albareed, 37. 


\section{Seventh: Airmail Department ${ }^{54}$}

A carrier pigeon Tower model and pair of embalmed homing pigeons are part of this section. A plane model "a gift from the Imperial Airways Company 55 ", airplane "a gift from Egypt Air ${ }^{56}$ for the Post Museum". An airplane model, "Gift from the Airways Corporation" and airplane model, "gift from the Dutch company K. L. M.

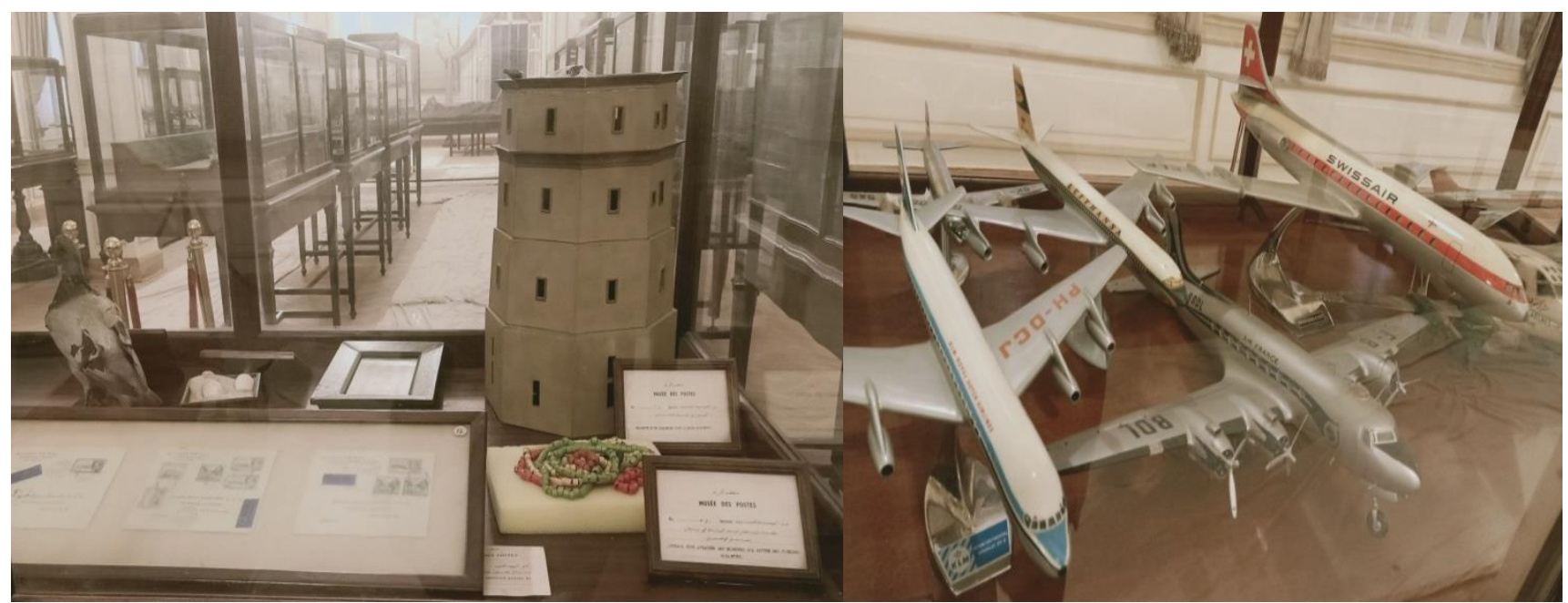

Figure 11: model of a carrier pigeon tower and various types of aircraft models used for transporting post

\section{Source:"Photographed by Authors"}

\section{Eighth: Foreign Post Section ${ }^{57}$}

A sword, trumpetand a pistol of a Sweden Post Guard in the last century, scale for correspondence in Germany and Postmen clothes in Germany. A car model for post deliveryin Germany and postman bag in Switzerland.
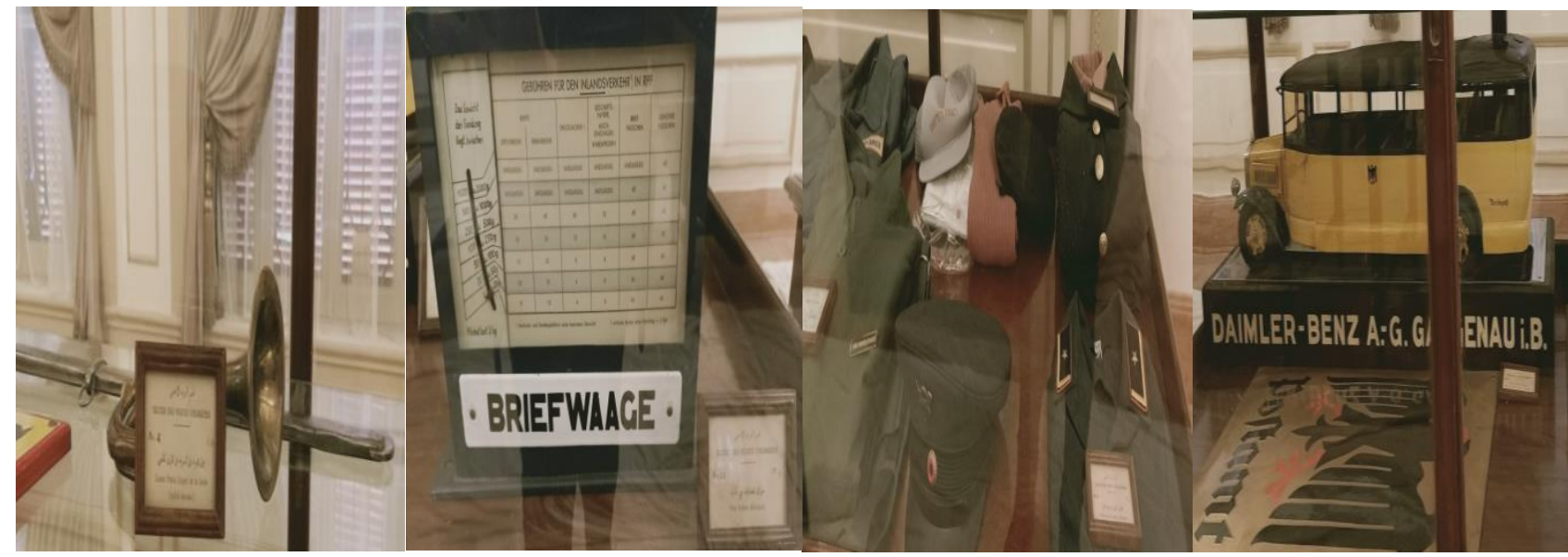

Figure 12: trumpet, scale, a car model and Postman clothes in Germany

\section{Source:"Photographed by Authors"}

\footnotetext{
${ }^{54}$ Transportation Ministry, Maslaht Albareed, Daleel Mathaf Albareed Almasry, 40-42

${ }^{55}$ In 1946 the helicopter was used for the first time in transporting post in the United States, in 1947 it was used in Europe between Netherlands and Belgium.

${ }^{56}$ The first Egyptian airmail line was used between Cairo and Baghdad In 1921, while the first Egyptian airmail stamp was issued in 1926 ; For More See; Ibrahim Marzook, Tareekh Twabec Albareed: Albedyia wa Alhwaya,( Cairo: Aldar Althaqafia llnashr, 2004), 102:107

${ }^{57}$ Ministère des communications:Administration des postes, "Guide du Musée postal égyptien., P 29: 30.
} 


\section{Ninth: Conferences Section}

This section Contains the international postal conferencessince the establishment of the first international post conference in Switzerland in $1874^{58}$ until the eleventh international post conference in 1939 in Buenos Aires ${ }^{59}$. This is the time period available in the Post Museum related with the international postal conferences. This is clear in the displayed photographs that show the members of each conference and its location, as well as the decisions and agreements related with each conference.

Also, a colored photograph of the memorial monument of the Postal Union in Bern, photograph of the members of the International Post in Bern 1874. The General Postal Treaty and the annexed agreements in the Conference of Bern 1874, a photograph of Dr. Stephen, founder of the Universal Postal Union in 1874.A photograph of the members of the International Post in Paris 1878. The General Postal Treaty and the agreements annexed to it in Paris Conference in 1878 and the General Postal Treaty and the agreements annexed to it in Lisbon Conference 1885. The General Postal Treaty and the agreements annexed to it in Vienna Conference 1891.A photograph of the members of the International Post in Washington 1897, aphotograph of the members of the International Post in Rome in 1906. A photograph of the members of the International Post in Stockholm 1924, photo of the members of the International Post and the conference location in London 1929, a photograph of the members of the International Post in Cairo in 1934 and the General Postal Treaty and the agreements annexed to it in Buenos Aires 1939.

\section{Tenth: Postage stamp Section ${ }^{60}$}

This section includes all kinds of ordinary, air, commemorative and governmental post stamps in the small hall of the Post Museum at Attaba ${ }^{61}$ in addition to foreign stamps i.e. stamps received from the Universal Postal Union, of which a portion is displayed inside the hall and another part in albums. All of these stamps are displayed inside glass panels in the form of a circular fan that is easy to move for viewing inside the museum's small hall. The hall contains printing tools such as clichés, molds, and plates for stamp making in its various stages. Next to a large model hanging on a large painting showing steps of printing work inside the museum's hall.

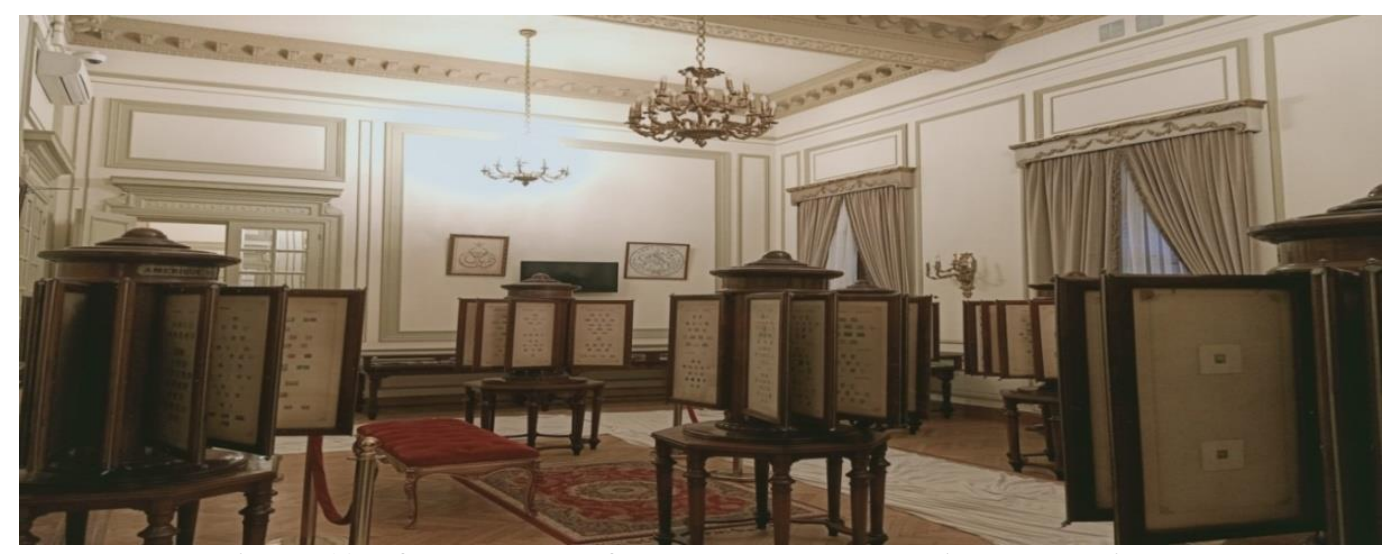

Figure 13: of the new hall for postage stamps during renovations.

Source:"Photographed by Authors"

\footnotetext{
${ }^{58}$ Egyptian National Archive: Portfolio 10, File 1, Conservation Unit 281, (Archival Code 000074-4024).

${ }^{59}$ Egyptian National Archive: Portfolio 61, File 12, Conservation Unit 198, (Archival Code 001449-0069).

${ }^{60}$ Ministère des communications:Administration des postes, "Guide du Musée postal égyptien,P 7: 10.

${ }^{61}$ Egyptian National Archive: Portfolio 839, File 1, Conservation Unit 235, (Archival Code 021069-0069).
} 
The small hall of the Post Museum includes a collection of classic portrait frames of Muhammad Ali, Ismail, Fouad and Farouk, besides stamps bearing the same images taken from paintings made by European artists for the family of Muhammad Ali, in addition to the tools used in the manufacture of stamps, such as the sheets of final experiments. printing plates and the covers of the first day of the issue ${ }^{62}$.The Post Authority also presented a new form of frames, by collecting stamps in a certain form to write the names of the rulers and their children on plates and placing each of them inside a glass frame such as writing the names of King Fouad, King Farouk, and Princess Ferial on the occasion of her birthday at the hands of the calligrapher Youssef Ramadan, an employee of the Survey Authority.

The post stamp exceeded the purpose for which it was established, which is the clearance of correspondence. It served other tasks such as hobbies, advertising, media, trade and culture. The authority issued a set of commemorative post stamps as a means of advertising in various fields in order that the stamp can roam all over the world through letters and correspondence. The idea of using the post seal as a means of publicizing state affairs arose in 1897, and after that the idea began to spread throughout the world ${ }^{63}$. Then countries started to use post stamps as a means of propaganda ${ }^{64}$, and doubtless it is the best advertising method, as it reaches everywhere in the world.

Also among the countries that used post stamps as a means of advertising are France, Belgium, England, Denmark and Italy. These countries allowed the publication of commercial advertisements for companies and institutions on stamps as did by New Zealand in 1882 and the United States of America between 1870 and 1880. But the use of stamps was canceled in this way in $1892^{65}$. That was what happened in Egypt in 1926 when "Shafiq Toma", a commercial shop owner, requested the publication of an advertisement on memorial stamps. However, the idea was rejected by the Director General of the Post Authority and the Minister of Communications for the unlawful use of post stamps as an advertising project although the implementation of the project will bring significant benefits to Egypt in material terms. It will also produce large amounts of money for the government treasures that can reach up to 14 million pounds, according to the number of daily messages sent inside and outside the country. But the committee considered that the project is not appropriate despite its benefits. On October 17, 1926, the Royal Adviser at the Ministry of Communications issues responded to this request, saying, "It is not permissible to write on stamps that are stuck on the cover of correspondence owned by their owners ${ }^{66} . "$

However, the Minister of Communications authorized government departments to use post stamps in advertising, after a request submitted by the Undersecretary of the Ministry of Agriculture to the Transportation Agent on June 11, 1933 to publicize Egyptian cotton. Also, on January 27, 1944, another request for publicity was sent by the Director of the Post Authority to the Undersecretary of the Ministry of Communications to make clichés for publishing some health advice for the purpose of health awareness,the request was approved by the Ministry. As a result of these requests and their approval, some ministries requested publicity for their products, such as the request issued by the Undersecretary of the Ministry of Agriculture to the Minister of Communications on June 29, 1944 regarding publicity from the "Fouad I Agricultural Museum". The text of the stamp should read "Visit the Fouad I Agricultural Museum in Dokki from 8 am: 1

${ }^{62}$ Majelat Alarab, $10^{\text {th }}$ October 2016, issue 10420

${ }^{63}$ Gary Osmond \& Murray G. Phillips, "Enveloping the Past: Sport Stamps, Visuality and Museums", (Routledge, ISSN: 0952-3367, Online Journal, 2011), homepage: https://www.tandfonline.com/loi/fhsp20.

${ }^{64}$ Egyptian National Archive: Portfolio 10, File 1, Conservation Unit 281, (Archival Code 000074-4024).

${ }^{65}$ Hussein Sherazy, Qesat Albareed, 51.

${ }^{66}$ Egyptian National Archive: Portfolio 10, File 1, Conservation Unit 281, (Archival Code 000074-4024). 
pm. And another request to the Minister of Communications on May 26, 1945 to make a cliché of the "Fouad I Museum for Post at Attaba" with the intent to publicize the Post Museum to use the cliché with the correspondence stamping machine in the department of Cairo Travel post on which "Visit the Fouad First Post Museum." (is inscribed in Arabic and French). Also, on October 11, 1950, the Post Authority asked the Ministry of Communications to advertise for Egypt abroad, and the advertisement was approved in Arabic and English by stamping the mail in the following formats ${ }^{67}$ :

Visit Egypt, land of sun shine, Nile and Magnificent Monuments.

On 1 June 1957, the Director General of the Post Authority made a suggestion to the Minister of Communications, that the stamps be used as a means of advertising for Egypt in all economic, financial, industrial, agricultural, educational, urban, tourism and other aspects. This publicity will be for the Post Museum, to guide the public about the services performed by the Post Authority, and for national and sporting events and all what shows the aspects of our modern renaissance through commemorative stamps. The Authority proposes to use some brief phrases to achieve the above-mentioned goals and to print them on millions of letters at home and abroad. And if the proposal has gained your acceptance, please agree to exchange 200 pounds and choose some phrases that satisfy you from among these examples for printing:

- Alexandria, bride of the Mediterranean Sea

- Egyptian beaches, the most beautiful beaches in the world

- $\quad$ Egypt, the cemetery of the invaders

- $\quad$ preserve your country's wealth by spending the summer on the Egyptian beaches

- initiate a contribution to industrial projects

- $\quad$ initiate a contribution to productive projects

- July 23 opening of the Council of Nations

- literacy is the goal of the government

- $\quad$ peace is the goal of Arabism

- Arab nationalism protects the entity of the Arab world

- the army of Egypt, the army of the Arabs

- Modern Egypt Part of Europe

- Egypt Tomb of Aggressors

- Egyptian Cotton is the Best in the World

It was approved by the Minister of Communications on June 4, 1957 to spend 200 pounds, and the following phrases were chosen:

- Alexandria, bride of the Mediterranean Sea

- Egypt, the cemetery of the invaders

${ }^{67}$ Egyptian National Archive: Portfolio 10, File 1, Conservation Unit 281, (Archival Code 000074-4024). 
- July 23, opening of the Council of Nations.

- $\quad$ Egypt Tomb of Aggressors

- Egyptian Cotton is the Best in the World

Thus, the propaganda continued on the postage stamp for what distinguishes the stamp for roaming in all countries of the world with ease and without cost. These features are not available to others in the advertising industry. The promotional words were written in Arabic, English and French to achieve the advertising goal ${ }^{68}$.

\section{CONCLUSIONS}

Egypt is one of the oldest countries in the world that witnessed the emergence of postal services. This is evidenced by the objects preserved inside the museum which contain pictures, maps, a group of graphs, and models of the development of the Egyptian postal service throughout ages. The museum also contains many documents such as: the first publication of the Post Service in its governmental era and the concession contract of the European Posta Company, in addition to a large rare wall painting on which are fixed 15 thousand stamps representing the scene of the pyramids and the Sphinx. The Egyptian Post Authority also confirms that the date of the first document in which the term "post" was mentioned dates back to 2000 years BC.

There is no doubt that the Post Museum is a national historic landmark that cannot be removed from the glorious history of Egypt. It is one of the great historical museums that narrate the history of the Egyptian Post in a new way that displays a collection of models (dioramas) of the means of transporting mail in the past and present, and samples of Egyptian and foreign stamps. in addition to The establishment of the Post Museum is a bright spot in the cultural history of Egypt.When the Post Museum was opened in 1934, the Postal Administration was affiliated with the Ministry of transportations. We find this clear in the museum's opening documents, when the Minister of transportations delivered the opening speech.

After the idea of using stamps as a means of propaganda appeared, the owner of one of the stores applied to a request for the Post Authority in 1926 to make propaganda for his own stores on post stamps. However, the idea was rejected by the Director General of the Post Authority and the Minister of Transportation, despite the benefits that would accrue to Egypt. However, the Minister of Transportation authorized government agencies to use post stamps to advertise Egyptian products. The Promotional words are written on post stamps in Arabic, English and French in order to achieve the goal of advertising without language hindrance.

King Fuoad ordered to establish a post museum on the second floor of the post Authority in 1930. In 1932, he ordered the authority to search for documents related to the history of post throughout the ages, to put them in the museum until the end of the International Postal Conference in 1934 by way of borrowing, but after the end of the conference the documents remained in the museum.

The Egyptian Post Museum was established on Attaba at a cost of LE 4430 on the occasion of the $10^{\text {th }}$ International Postal Conference in Cairo from February 1 to March 20, 1934.After that Egypt's encyclopedia has expanded with countries around the world due to direct dealings through attending international conferences, whether inside or

${ }^{68}$ Egyptian National Archive: Portfolio 10, File 1, Conservation Unit 281, (Archival Code 000074-4024). 
outside Egypt.In addition, the photographs found inside the Post Museum, they show the difficulties that the postman encountered in transporting the letters. He used to write his will before leaving due to the monsters, attacks and bandits he encountered on the road.

Post Museum was opened at Attaba more than once. The first opening was in 1934 during the holding of the Tenth Post Conference. Then onJanuary 2, 1940 during the official opening to the public. It was closed during World War II and reopened in 1946 after the end of the war. It was also closed to make some adjustments during the rule of President Mubarak until it was inaugurated on February 7, 1989. Currently, the museum was closed again to carry out renovations and upon completion it will be opened in the near future.

One of the methods used to register the holdings inside the Post Museum is to write the name of the museum in both Arabic and French and write the section of each piece, given that the museum contains ten sections, then the plot number and record all the data in full, as well as the place from which it was obtained.

It is worth noting here that the Egyptian Post Museum has the ability to preserve treasures of the past from damage and loss that lasted for hundreds of years through its various sections that brought together many holdings despite their different types. It contains papers, letters, models for transportation, paintings, pictures, documents, gifts, boxes for letters, scales, clothes, Egyptian and foreign stamps, maps and graphics. This is in addition to what the museum owns of a special and unique nature, as it is the only museum that is included within a government building for citizens' post services and not independent of itself. Currently, the responsible authorities in the state are carrying out renovations to the museum that began in September 2019, and work is still underway inside the museum so far for the opening as soon as possible.

Thus, the Egyptian Post Museum continues its aid to enlighten the cultural life in contemporary Egyptian life because of its great importance that makes it a cultural and educational institution for future generations by displaying a distinguished group of rare collections that are important documents. and this diversity in museums is a point of strength.

\section{REFERENCES}

1. Egyptian National Archive, Archival Code,(001443-0069).

2. Portfolio 8, File 1, Conservation Unit 309, Archival code, (000151-4015).

3. Egyptian National Archive, Portfolio 10, File 1, Conservation Unit 281, (ARC 000074-4024).

4. Al Ahram, 19 $9^{\text {th }}$ January 1940, issue 19886.

5. Egyptian National Archive, Archival code(001443-0069).

6. Hussein Sherazy, Qesat Albareed, ( Cairo: Dar Elketab Alaraby, 1967), 28-29.

7. Egyptian National Archive, Portfolio 1, File 3, Conservation Unit 309, Archival code(000003-4015).

8. Abd Elrahman Zaki, Mawsact Madinat Alqahra fi Alf Am, 8th edition, ( Cairo: Anglo press, 1987), 24.

9. Ahmed Yasser, "postal Museum: Reference for stamp Collectors in Egypt", in Sada El-balad journal, Wed. 19/12/2018 24/1/2019, 12: 26pm (,Thurs).

10. Majalt Alarab, $10^{\text {th }}$ October 2016, issue 10420.

11. Transportation ministry, Maslaht Albareed, Daleel Mathaf Albareed Almasry,( Cairo: Amiria Press, 1934), 40-42. 
12. Mohaamed Fawzy Abdelqader, Vector Anton Ibrahim, Rwad Albared Almasry, ( Cairo: Alheah Alqwmia llbareed, 2010), 175:200

13. Egyptian National Archive, Archival code(001443-0069).

14. Egyptian National Archive, Portfolio 61, File 12, Conservation Unit 198, Archival code(001449-0069).

15. Al Ahram, $19^{\text {th }}$ January, 1940, issue 19886.

16. Al Ahram, $2^{\text {nd }}$ February 1934, issue 176560.

17. Egyptian National Archive, Archival code(001443-0069).

18. Egyptian National Archive, Portfolio 60, File 1, Conservation Unit 198, Archival code(001429-0069).

19. Saleh Abdoon, Khamsoon Amn mn Almwseqa wa Alopera, (Cairo: Dar Alshrooq, 2017), 101.

20. Samy Mohamed Feraj, Bareed Masr Almahrwsa tht Hkm Osrat Mohamed Ali(1914-1957), vol.2, ( Cairo: Dar Elreda, 2017), 101.

21. Ahmed Hussein Hafez, Swaran Tahky Tareekh, ( Cairo: Almanhal, 2014), 22.

22. Alwaqac Almasria, $16^{\text {th }}$ October 1930, issue 96.

23. Ministère des communications : Administration des postes ‘"Guide du Musée postal égyptien ‘ (Imprimerie National Le caire، 1934) P 29: 30.

24. Transportation ministry, Maslaht Albareed, Daleel Mathaf Albareed Almasry, 42-43.

25. Zeitouna, "150 years of Egyptian Postage 1866-2016",(first edition, Dar El Kutub, Cairo, 2015).

26. Egyptian National Archive,Portfolio 1, File 3, Conservation Unit 309, Archival code (0000o3-4015).

27. Abd Elhaleem Abu Seer, Ismail Abdelfatah, Jawla Dakhel Mathaf Albareed, (Cairo: Alhaea Alamah Llestalamat, 1999), Tansportation Ministry, Maslaht Albareed, Daleel Mathaf Albareed Almasry, ( Cairo: Amirira press, 1934).

28. Alahram, $2^{\text {nd }}$ February, 1934, issue 176560.

29. Egyptian National Archive, Portfolio 10, File 1, Conservation Unit 281, Archival Code, (000074-4024).

30. Almoqatm, $18^{\text {th }}$ January 1940 , issue 15705

31. Abd Elrahamn Zaki, Mawsact Madinat Alqahia fi Alf Am, 241.

32. Egyptian National Archive, Portfolio 61, File 12, Conservation Unit 198, Archival code(001449-0069).

33. Majalet Alarab, $10^{\text {th }}$ October, 2016, issue 10420

34. Egyptian National Archive, Portfolio 5, File 2, Conservation Unit 309, Archival Code (000052-4015).

35. Egyptian National Archive, Archival Code (001443-0069).

36. Alahram, $19^{\text {th }}$ January, 1940, issue 19886.

37. Mohamed Fawzy Abdelqader, Vector Anton Ibraheim, Rwaad Albareed Almasry, 151-152.

38. Egyptian National Archive, (001443-0069).

39. Almoqatem Newspaper, $18^{\text {th }}$ January, 1940, issue 15705. 
40. Wezarat Almwaslat, Daleel Mathf Albareed Almasry, 1:6.

41. It is a memorial plate commemorating the victories of King Narmer, founder of the First Dynasty in 3200 BC, who was able to unite the Kingdom of the South with the North. This painting was discovered in 1898 in the city of Hirakonouples.

42. Abd Elhaleem Abu Seer, Ismail Abdelfataf, Jawla Dakhel Mathaf Albareed, 36.

43. Ministère des communications:Administration des postes, "Guide du Musée postal égyptien, P 11:18.

44. Majalt Alkarab, $10^{\text {th }}$ October 2016, issue 10420

45. Abd Elhaleem Abu Seer, Ismail Abdelfataf, Jawla Dakhel Mathaf Albareed, 23:36.

46. ${ }^{1}$ Ministère des communications: Administration des postes, "Guide du Musée postal égyptien, P 19:21.

47. Abd Elrahman Zaki, Mawswact Madinat Alqahra fi Alf Am, 240.

48. Wezarat Almwaslat, Daleel Mathf Albareed Almasry,32.

49. ${ }^{1}$ Abd Elhaleem Abu Seer, Ismail Abdelfataf, Jawla Dakhel Mathaf Albareed, 37.

50. Majalt Alkarab, $10^{\text {th }}$ October 2016, issue 10420

51. Abd Elrahman Zaki, Mawswact Madinat Alqahra fi Alf Am, 240.

52. Wezarat Almwaslat, Daleel Mathf Albareed Almasry, 36:39.

53. Abd Elhaleem Abu Seer, Ismail Abdelfataf, Jawla Dakhel Mathaf Albareed, 37.

54. Transportation Ministry, Maslaht Albareed, Daleel Mathaf Albareed Almasry, 40-42

55. In 1946 the helicopter was used for the first time in transporting post in the United States, in 1947 it was used in Europe between Netherlands and Belgium.

56. The first Egyptian airmail line was used between Cairo and Baghdad In 1921, while the first Egyptian airmail stamp was issued in 1926 ; For More See; Ibrahim Marzook, Tareekh Twabec Albareed: Albedyia wa Alhwaya,( Cairo: Aldar Althaqafia llnashr, 2004), 102:107

57. Ministère des communications:Administration des postes, "Guide du Musée postal égyptien., P 29: 30.

58. Egyptian National Archive: Portfolio 10, File 1, Conservation Unit 281, (Archival Code 000074-4024).

59. Egyptian National Archive: Portfolio 61, File 12, Conservation Unit 198, (Archival Code 001449-0069).

60. Ministère des communications:Administration des postes,"Guide du Musée postal égyptien,P 7: 10.

61. Egyptian National Archive: Portfolio 839, File 1, Conservation Unit 235, (Archival Code 021069-0069).

62. Majelat Alarab, $10^{\text {th }}$ October 2016, issue 10420

63. Gary Osmond \& Murray G. Phillips, "Enveloping the Past: Sport Stamps, Visuality and Museums", (Routledge, ISSN: 09523367, Online Journal, 2011), homepage: https://www.tandfonline.com/loi/fhsp20.

64. Egyptian National Archive: Portfolio 10, File 1, Conservation Unit 281, (Archival Code 000074-4024).

65. Hussein Sherazy, Qesat Albareed, 51.

66. Egyptian National Archive: Portfolio 10, File 1, Conservation Unit 281, (Archival Code 000074-4024). 

Ahmed \& Mohamed Atef Abdel-Maksood

67. Egyptian National Archive: Portfolio 10, File 1, Conservation Unit 281, (Archival Code 000074-4024).

68. Egyptian National Archive: Portfolio 10, File 1, Conservation Unit 281, (Archival Code 000074-4024). 